\title{
HOW SYSTEM OF SETTLEMENTS IN SERBIA WILL CHANGE? GEOGRAPHIC DETERMINANTS OF SPATIAL-FUNCTIONAL RELATIONSHIPS OF URBAN AND RURAL AREAS
}

DOI: https://doi.org/10.18509/GBP210461k

UDC: 911.373:911.375]:711.13(497.11)

\author{
Nikola Krunić \\ Aleksandra Gajić \\ Danijela Srnić \\ Institute of Architecture and Urban \& Spatial Planning of Serbia, Serbia
}

\begin{abstract}
System of heterogeneous settlements in Serbia was shaped by phenomenon and processes rooted in their geographical position: accessibility, population dynamics, socio-economic transformation and functional capacity of the centers. This paper examines future spatialfunctional development of the national urban system (consisting from urban and rural areas) with focus on geographical determinants and population dynamics. The research provides an overview of the key geographical factors and processes which influence development of the urban system. The aim of the paper is to predict future spatialfunctional relationships between urban and rural areas of Serbia in the line and context with the official projection of the population. The result should contribute to wider discussion about new implementation models in the new generation of spatial planning documents.
\end{abstract}

Keywords: urban centers, urban and rural areas, population dynamics, Serbia.

\section{INTRODUCTION}

Urban centers, urban and rural areas which compose urban systems in Serbia represent heterogeneous set of settlements which differs in demographic size, economic development and functional capacity. This is a consequence of different development predispositions in geographical and socio-historical context. Similarly, to the most of Southeast Europe, Serbia is not sufficiently urbanized compared to the most developed part of the continent. Serbia was affected by intensive urbanization only in the second half of the twentieth century. Until the 1960s, Serbia had a predominantly agricultural character in terms of economic structure, and was rural environment in terms of population structure [1]. Small urban centers dominate in the spatial-structural and functional organization of the settlement network. At first glance, it can be concluded that the urban network of Serbia is characterized by the favorable position of urban settlements, however, a more detailed analysis of the concentration of population and functions indicates numerous problems and challenges of their spatial development

\section{SPATIAL ASPECTS OF SETTLEMENT DISTRIBUTION AND DEVELOPMENT}

The spatial distribution of cities is largely conditioned by physical and geographical characteristics of Serbian geospace. This is indicated by a clear correlation between the 
spatial distribution of the population, the average altitude and the intensity of construction (percentage of land covered with build-up areas) [2], [3].

Research shows that urban centers at lower average altitudes tend to have more intensive level of construction. Therefore, settlements in the area of Belgrade, Vojvodina, Niš, Priština, as well as cities along the West Morava River have the highest intensity of construction [2], [3], [4]. The lowest intensity of construction is in cities located in southeastern Serbia, which is a predominantly mountainous area. There is a strong correlation between the spatial distribution of the population and the intensity of built-up areas. Densely populated parts of urban areas also have a higher intensity of construction, which supports the thesis that the urban settlements, i.e. their central and planned zones are still relatively compact [2], [3]. In the structure of build-up areas, the classes of discontinuous urban fabric with very low density have the largest share (19\%), while as discontinuous urban areas of medium and low density of construction have equal share of around $15 \%$ (based on Urban Atlas - UA) [5]. Furthermore, this is confirmed by changes in land cover (according to CORINE), and it can be concluded that the total increase of settlement area, from 2012 to 2018 was only about $2 \%$, mostly in the vicinity of Belgrade and Novi Sad, whereas the greatest intensity of changes was noticed in the urban area of Priština.

Regarding transport accessibility, which is measured with distance of settlements from the nearest urban centers (travel-time), it is confirmed that the settlements near the centers located along the main development axes have better accessibility. This mainly refers to the Danube-Sava development axis. At the level of statistical regions, there are significant differences between Belgrade and Vojvodina compared to other regions of Serbia. Due to a more developed local road network and favorable geographical and transport position, majority of the settlements in the area of Vojvodina are covered within 45minute isochrone of a more developed urban center. Settlements in the area of Sumadija and parts of Western and Southern Serbia within the scope of the Morava and West Morava development axes also have favorable accessibility. Border parts and mountainous areas of northeastern Serbia, eastern, southern and southwestern Serbia have low transport accessibility. Due to weak development of traffic infrastructure and unfavorable physical-geographical characteristics, these areas are far beyond the 45minute of leading centers of work and services.

\section{POPULATION DISTRIBUTION AND FUNCTION CONCENTRATION}

Due to high disparities in demographic size and demographic potential, territorial coverage and diversification of functions, as well as the difference in size of their spheres of influence, urban centers in Serbia have various roles and significance in the territorial integration of Serbia.

The discrepancy between the population of the leading and other urban centers shows that Serbia does not have a properly and evenly developed urban system, i.e. that the flows of urbanization were not timely directed towards a more balanced spatial distribution. The polarization effects of urbanization, spatially manifested by demographic and economicfunctional concentration, are also expressed in the majority of statistical regions. The disproportion in the demographic size of Belgrade and other larger cities is a consequence of the incoherence and asymmetry of the urban system of Serbia. Changes in urban systems are very slow, and spontaneous mitigation of territorial disparities cannot be expected in the near future. Deficiency is noticeable in terms of evenly distributed urban centers with 100,000 to 200,000 inhabitants and absence of centers with 300,000 to 
500,000 inhabitants with developed macro-regional functions, which would lead to the balanced internal development of Serbia. Relevant facts and the experience of countries that have a similar urban system show that no major changes will take place in this field in the coming period.

The spatial disproportion of functions is manifested with an increase and concentration of functions in the most important urban areas in Serbia and with a significant reduction in the functional capacities of other urban areas and urban centers, as well as their territorial influence, which leads to the population to other places, i.e. abroad.

The functional capacities of urban centers have been significantly reduced, which is reflected in the reduction of space under their direct influence. More than $1 / 3$ of the settlements are not part of any urban area. It is noticeable that most centers of urban areas integrate mainly settlements that belong administratively to them, while only areas of Belgrade, Novi Sad, Priština, Niš and Kragujevac integrate into their sphere of influence a territory wider than administrative. On the contrary, some important urban centers such as Novi Pazar, Kraljevo, Bor and Pirot fail to integrate even the settlements of their administrative territory. This fact is further supported by the analysis of the structure of daily migrants of the economically active population who perform the occupation of settlements within the urban area. Only Belgrade, Novi Sad, Priština and Niš are destinations for a significant number of daily migrants from the territories of other local self-government units. Moreover, Kragujevac, Vranje, Požarevac, and Valjevo have a certain subregional influence. In addition, urban areas overlap, so some of them have the characteristics of polycentric and hierarchically structured systems.

In urban areas, the largest functional transformations occurred in the central and periurban zone of urban centers. The urban center specializes in the tertiary sector, while the secondary sector is relocated to peri-urban settlements in isochrony of daily migrations. However, the organization of local transport, communal infrastructure, as well as the function of housing, are not adapting fast enough to these changes. Thus, the settlements of the peri-urban zones have almost no public infrastructure and facilities.

Analysis of daily migration indicates the development of the labor market and intensity of the impact that the urban center has on the immediate surroundings. Majority of urban centers make impact only to the nearby settlements within their administrative territories. However, it is confirmed that the daily migration is mainly noticeable in the areas which are leading development and business centers - Belgrade, Novi Sad and Niš, while smaller migration systems are formed along the development axes and in the centers of Kragujevac, Valjevo and Novi Pazar.

In rural areas, the process of demographic fragmentation of villages is pronounced, which is a consequence of long-term depopulation. Population-large settlements are located in the region of Vojvodina and the region of Belgrade. As a consequence of unfavorable demographic trends, undirected and uncontrolled migration flows, the age, economic and educational structure of the population has been disrupted. Regarding the average age of the population, a clear regional imbalance is expressed. On average, the oldest population is registered in the southern, eastern and southwestern rural settlements, where some villages already lost their permanent inhabitants. Recent research that takes into account several different indicators of rurality / urbanity indicates several tendencies in the spatial distribution of the population in rural areas in Serbia. The dominant areas of growth are the rural areas around Belgrade, Novi Sad and Niš. Other rural areas are exposed to negative demographic tendencies, which are especially present in the mountainous and peripheral parts of eastern, southwestern and southern Serbia [4], [6]. 


\section{FUTURE PERSPECTIVES}

Among the numerous challenges to the development of urban centers in Serbia, two stand out as the most significant - depopulation and reduction of functional capacities of urban centers. Depopulation is not a problem only from the aspect of population reduction, but the collapse of the socio-economic structure, reduction of the quality of the labor force, deterioration of the age of the population, low fertility, etc. A new component in further strengthening depopulation in Serbia is the increasingly pronounced emigration of the high-quality workforce, that will progress in the future, which is recognized as one of the biggest national challenges. In the cause-and-effect relationship with depopulation is also a reduction in the number and spatial range of functions of urban centers, i.e. a reduction of the impact of urban centers to the surroundings. Nevertheless, favorable condition for the urban development are better infrastructural connections which will follow with the completion of the construction of transport corridors and accompanying facilities, as well as the started process of reindustrialization.

Internal problems of urban centers that stand out are: usurpation of public space, substandard quality of housing and utilities, violation of environmental quality, social segregation, sometimes even gentrification. Finally, for urban centers in Serbia, global challenges which are persist in the wider regional environment and Europe are becoming increasingly important, while internal and specific ones are becoming less significant.

Based on ESPON (European Spatial Planning Observation Network) research, it can be concluded that the level of polycentricity has decreased in all European countries in the past two decades. The reason for this is the increased accessibility of large centers, as well as economic development and population growth in large metropolitan areas. The process of reducing polycentricity is expected to continue in the future, as indicated by all the scenarios considered. European Union (EU) member states (which joined in 2005 and after) initially had a more favorable polycentric development of urban centers than the "core" of the EU, but the process of declining polycentricity was faster in the newly acceded countries, with an emphasis process of accelerating centralization. Socioeconomic transformations and their spatial manifestation in the urban systems of the former socialist states, which are now members of the EU, have many common characteristics with the development of the urban system of Serbia, and all indicate intensified polarization and accelerated development of the center-periphery structure [7]. Urban systems will be transformed, both positively and negatively, in conditions of continuous population decline. In general, urban and rural settlements will be demographically reduced, with certain exceptions, which refer to certain suburban settlements - parts of peri-urban rings of larger urban areas.

The share of the urban population will increase. The intensity of the reduction of the population of urban centers will depend on their demographic size, natural and migratory trends and qualitative ones, i.e. structural features of the population, and will certainly be more pronounced in medium and small urban centers.

Daily urban systems have been formed, the number of daily migrants will stagnate in most cases, and will decrease over time. In the Danube-Sava development zone and agglomerations, daily migration will be developed according to the system of "urban context", and in other urban areas it will take place according to the traditional hierarchical model.The zones of direct influence of urban centers will decrease with the intensification of daily migration of the population, while urban areas will be extended due to the development of traffic infrastructure, but there will be less inhabitants, so the contingent of those participating in daily migration will be also reduced. 
The development of major roads will have a positive effect on the integration of centers in the central part of Serbia, and will, to some extent, qualitatively strengthen the connections to the border areas. Mobility will increase, and the trend of development of electronic communications will provide greater autonomy of the individual and business (expansion of work on the move, from home, etc.), regardless of the location of the company.

The concentration of the economy in agglomerations and along development axes will continue (except for those that depend on the location of resources such as the exploitation of mineral resources). The automation of production and business will have a great impact on the spatial distribution and structure of the workforce.

In rural areas, villages will not be able to integrate their surrounding rural area, so this role will be taken over by local urban centers with the development of specific functions (tourism and complementary activities, seasonal housing, etc.).

Generally, it can be said that Serbia is a country in which, to a greater or lesser extent, the spatial-developmental dichotomy "center - periphery" is expressed at all territorialadministrative and territorial-functional levels. The differences between the core and the periphery are refracted in transitional forms which, depending on numerous geographical, socio-economic, spatial-functional, territorial-administrative and other specifics, have different nuances and dimensions. Conditionally, it manifests in the form of semiperipheries, which is fragmented into parts that have the intention of joining the core and parts that are increasingly taking on the characteristics of the periphery.

\section{Acknowledgement}

This paper presents the results of research realized in scientific research projects supported by the Ministry of Education, Science and Technological Development of the Republic of Serbia, as well as research for the needs of drafting the Spatial Plan of the Republic of Serbia in the period 2021-2035.

\section{REFERENCES}

[1] Tošić D \& Nevenić M. Nodalna regija instrument prostorno-funkcionalne organizacije Srbije, Zbornik radova Geografskog instituta „Jovan Cvijićc" SANU, Serbia, vol. 57, pp. 297-307, 2007.

[2] Krunić N., Bajat B \& Kilibarda M. Dasymetric Mapping of Population Distribution in Serbia Based on Soil Sealing Degrees Layer. In Rủžičková K \& Inspektor T. (eds.), Surface Models for Geosciences. Lecture Notes in Geoinformation and Cartography, pp. 137-149. Springer, Cham, 2015.

[3] Krunić N., Gajić A., Srnić D \& Tošić D. Spatial aspects of demographic processes in Serbia, Stanovništvo, Serbia, vol. 56, no.2, pp. 23-38, 2018.

[4] Gajić A., Krunić N \& Protić B. Towards a new methodological framework for the delimitation of rural and urban areas: a case study of Serbia. Geografisk Tidsskrift-Danish Journal of Geography, vol. 118, iss. 2, pp.160-172, 2018.

[5] Гајић A \& Крунић Н. Примена података „Urban Atlas” у истраживању и планирању простора, In: Петрић J \& Вујошевић M. (eds.) Теоријска, развојна и примењена истраживања просторних процеса за обнову стратешког мишљења и управљања у Србији, Посебна издања 2, ИАУС, Serbia, pp. 67-85, 2020.

[6] Gajić A., Krunić N \& Protić B. Classification of Rural Areas in Serbia: Framework and Implications for Spatial Planning, Sustainability. vol.13, iss. 4, 2021.

[7] ESPON. Potentials for polycentric development in Europe. Project 1.1.1, Project report, Luxembourg, 2005. 